\title{
Drømmen om skolen i Soer
}

\author{
Af Gustav Albeck
}

Hvad blev der af Grundtvigs drøm om Skolen i Soer?

Der skal nok være dem, der har et hurtigt svar for hånden og vil sige, at spørgsmålet er let at besvare: Der blev den danske Folkehøjskole - samt den norske og beslægtede tiltag i Sverige og Finland og nogle andre lande på vor klode. Og svaret er for så vidt rigtigt, men næppe fyldestgørende.

Selvom Grundtvig så et lyspunkt i oprettelsen af Røddingskolen i 1844 og de andre små skoler (bondeskoler, som man kaldte dem, ikke for at være nedladende, men for at præcisere deres funktion og målgrupper), opgav han aldrig drømmen om den store Højskole i Sorø. Først da den unge danske Rigsdag sagde nej til den af Christian VIII approberede plan om en stor statshøjskole i Sorø, indså han, at han ikke fik opfyldelsen af sin store drøm at se. Så meget mere fandt han trøst ved tanken om de mange folkehøjskoler, der myldrede frem i de sidste årtier af hans liv. Og så meget mere fjernede han sig fra sin oprindelige plan om et folkeligt akademi, et borgerligt åbent universitet, en slags videreførelse af det center for Danmarks historie, som Grundtvig var overbevist om, at Absalon havde haft i sine tanker i forbindelse med oprettelsen af Sorøklostret, sådan som det bl.a. skildres i den tyske udgave af den gamle danske Rimkrønike og hos Arild Hvitfeld i hans Danmarkshistorie, men først og sidst en moderniseret udgave af det borgerlige akademi (som Holberg havde støttet med betydelige donationer).

Det er ikke hensigten i det følgende at gøre rede for de forskellige faser $\mathrm{i}$ udformningen af Grundtvigs visioner vedrørende et genskabt Sorø Akademi. Jeg nøjes med at henvise til professor K.E. Bugges kyndige redegørelse i disputatsen "Skolen for Livet"

En mere omfattende skildring af emnet vil indgå i forfatterens bog Universitet og folk, der udkommer på Gyldendal ved udgangen af 1983. 
(1965), men må dog fremdrage enkelte punkter i denne udvikling for at tydeliggøre min opfattelse af grundtankerne i Grundtvigs planer.

Et af de ældste vidnesbyrd om, at hans Sorøvisioner (der kan føres helt tilbage til hans grønne ungdom) var ved at tage form, er et par udkast, han skrev i 1827, efter at han i et nr. af "Edinburgh Review " havde læst om planerne vedrørende rejsningen af University of London. Her var tale om et revolutionært skridt inden for den engelske universitetsverden, der gennem århundreder havde været behersket af de gamle og store universiteter i Oxford og Cambridge. Universitetet i London blev rejst på privat initiativ - af borgere i London, som ønskede en videnskabelig læreanstalt for ikke-akademiske borgersønner, en dannelsesanstalt, der ikke specielt havde til formål at uddanne embedsmænd eller videnskabsdyrkere.

Tanken optog Grundtvig i den grad, at han satte sig til at udtænke en plan for et genskabt Sorø Akademi efter det londonske projekts mønster. - Desværre har vi kun nogle fragmenter af hans manuskripter vedrørende denne sag. Og han lod intet deraf trykke. Heraf skal man da ikke slutte, at han vragede de tanker, han havde mødt $\mathrm{i}$ den engelske journal. De levede videre hos ham til ny udformning, efter han ved selvsyn havde lært den engelske universitetsverden at kende under ophold $\mathrm{i}$ såvel $\mathrm{Ox}-$ ford som Cambridge. Her lærte han et andet og friere universitetsbegreb at kende end det kontinentale, for ikke at sige det tyske eller prøjsiske, der i nogen grad prægede det danske. Hans oprindelige Sorøplan sugede næring fra såvel de gammeldags universiteter i Oxford og Cambridge som fra det "moderne" universitet i London. Fra det sidste hentede han tanken om et åbent, "folkeligt" universitet frigjort fra latintraditionen og andre levn fra middelalderen. På de gamle engelske universiteter mødte han troen på det gavnlige i kollegiesystemet, det daglige samliv mellem de studerende indbyrdes og mellem studenterne og deres lærere.

Det nybrud i hans tilværelsessyn, som Englandsopholdene kom til at betyde for ham, førte ham ind i nye og dybere overvejelser 
om problemet videnskaben overfor den akademiske dannelse.

I en anmeldelse som Grundtvig skrev i slutningen af 1830 , taler han om "Misforholdet mellem det folkelige og det professorlige i Videnskabeligheden ", et misforhold, som han mener er ejendommeligt for Tyskland, men desværre også har taget overhånd i Norden og "truer med et Barbari«.

„Naar ... de lærde ikke kan eller vil skrive livligt og forstaaeligt, men misbruger deres Skolekundskaber til at drille og trætte de Ulærde ... maae Følgen nødvendigvis blive Ringeagt hos de Ulærde for SkoleStudierne ...

Vel gør jeg ikke Profession af Lærdom og indrømmer gerne, at jeg er kun en Lærling i den folkelige Fremstilling, men dog kender jeg nok til begge Dele for inderlig at ønske dem forenede. Og for at sky saavel Anmasselsen og Løseligheden, der sædvanlig hænger ved den ene, som Kryheden og Pedanteriet, der saa hyppigt ledsager den anden, saa har jeg grundet meget paa, hvordan det sørgelige Misforhold kunde hæves. Det bedste Middel hertil har jeg fundet at ville være Oprettelsen af en Højskole for populær (folkelig) Videnskabelighed, der holdt Universitetet i Skak og holdtes ligedan af det; men da Professorerne naturligvis ville ansee sligt for et grueligt Indgreb i deres Privilegier, er der for Øjeblikket ej nogensteds Udsigt til en saa ønskelig Ting."

Som Grundtvig udtrykker sig her i 1830, er det forholdet mellem universitet og folk, der optager ham, ønsket om at kunne forene den videnskabelige med den folkelige fremstilling, eller med et af Grundtvigs yndlingsbegreber -: Vekselvirkningen mellem den akademiske og den folkelige dannelse.

Noget stort håb om, at en sådan vekselvirkning kunne komme i stand, synes han ikke at have næret i 1830. Men en halv snes år senere kommer optimismen til udtryk. Og noget tyder på, at det var hans gamle modstander, H.C. Ørsted, som havde bidraget til at give ham et lysere syn på muligheden af at realisere Sorø-tanken.

Det ses af en ufuldendt artikel, som Grundtvig skrev i 1839 til Fr. Barfods tidsskrift "Brage og Idun", og som Holger Begtrup har fremdraget og trykt i sit "Tidsskrift" (1905).

Grundtvig havde fæstnet sig ved det folkeoplysende arbejde, der udgik fra H.C. Ørsteds nyoprettede læreanstalt (den polytekniske), og som fik et folkeligt forum i "Selskabet til Naturlærens Udbredelse". Da Grundtvig samtidig havde haft succes med sine "Mands Minde-forelæsninger", sluttede han aktivt op 
om Fr. Barfods initiativ til dannelsen af et humanistisk sidestykke til Ørsteds selskab: "Danske Samfund ".

Ørsteds folkelige oplysningsvirke inspirerede Grundtvig til en lovtale over "Naturforskernes Praxis, der har faaet dem til at udrette utrolige og efter vore Fædres Maalestok umulige Ting og vakt Forventninger om endnu langt større, ja mangensteds frembragt den Tro, at for dem ... er ingen Ting umulige. "

Grundtvig nævner i denne forbindelse: "Luft-Maskiner, Damp-Skibe og -Vogne", og skriver om naturforskerne, at

"de reise saa vidt muligt til Maanen og udhule Jorden til Afgrunden ... de mødes fra alle Sider til Bekiendtskab og Vexelvirkning, nøies hverken med deres Deel af de gamle Universiteter eller med den udelukkende Besiddelse af Videnskabs-Selskaberne, men vinde nye Højskoler, stifter folkelige Selskaber og stræber af al Magt baade med Mund og Pen at meddele Udbyttet af deres Granskning, vakke Beundring for deres Opdagelser, Ærbødighed for deres Øiemed, Deeltagelse i deres Sysler og Forstand derpaa. "

Det var en lignende opgave, Højskolen i Sorø - ifølge Grundtvigs oprindelige tanker - skulle løse. Styrket i sin tro på det folkelige, historiske foredrags betydning ved de vellykkede "Mands-Minde-forelæsninger" i 1838 sluttede Grundtvig aktivt op om "Danske Samfund " som en slags forsøgsordning vedrørende den kommende folkelige Højskoles virke. Drømmen herom fik Grundtvig ikke set opfyldt. Men tanken døde ikke med sin ophavsmand. Nye stridsmænd søgte i årtier efter Grundtvigs død at genoplive den.

Allerede 6 år før Grundtvig døde henvendte Soransk Samfund på initiativ af redaktør Steen Bille - sig til kultusminister Rosenørn-Teilmann med ønsket om, at der blev nedsat en "Komission til at undersøge Sorø Akademis Stilling bl.a. for at realisere dets gennem Aarhundreder fastholdte Formaal: at være en fri Skole for højere Dannelse. "

Institutionen Sorø Akademi lå i hine tider inde med betydelige pengemidler - mange flere, end der gik til driften af Sorø Akademis lærde Skole, kostgymnasiet.

Rosenørn-Teilmann nedsatte en kommission, hvori bl.a. to 
grundtvigske politikere ( $H$. Carlsen og L. Dinesen) havde sæde. De kunne ikke tilslutte sig betænkningen, hvis forslag var præget af den ene af Københavns Universitets to repræsentanter $i$ kommissionen, filosoffen, professor Rasmus Nielsen. Hans plan gik ud på at oprette en statshøjskole, hvortil der krævedes en optagelsesprøve af eleverne, og som skulle virke gennem kurser af to års varighed, sluttende med en modenhedsprøve. Altså en eksamen! Det var ikke just i Grundtvigs ånd. Ejheller et forslag om at flytte den statsvidenskabelige fagskole fra Københavns Universitet til Sorø. Selvom undervisningsfagene iøvrigt omfattede de fag, som Grundtvig havde foreslået i sine højskoleskrifter, måtte kommissionens grundtvigske medlemmer tage afstand fra forslaget. Bødlen, der definitivt ombragte planen, var ingen ringere end Madvig, som også i 1849 havde ført sværdet mod Christian VIIIs forslag. Ministeren havde afæsket Madvig en erklæring, og han lagde ikke fingrene imellem.

Navnlig lod han det gå ud over Rasmus Nielsen, der fik nogle ondskabsfulde stik af sin berømte kollegas spidse pen.

Nielsen nød stor anseelse og popularitet i grundtvigske kredse. Selv holdt han jævnligt folkelige foredrag, ikke blot i hovedstaden, men også ude i landet. Han udgjorde et helt lille Folkeuniversitet, årtier før tanken om en dansk university extension slog rod. Man kan i adskillige af hans skrifter i tiden om og efter 1867 følge hans overvejelser over, hvorledes man kunne virkeliggøre Grundtvigs tanker om en vekselvirkning mellem den akademiske og den folkelige dannelse.

I et af de foredrag, han i 1867 holdt i Kristiania, og som han udgav som bog med titlen "Hindringer og Betingelser for det aandelige Liv i Nutiden ", sagde han - med tydelig henvisning til det arbejde, som udførtes i den førnævnte Sorø-Kommission:

"Det gjælder i Nutidens aandelige Liv om Vexelvirkning mellem Videnskab og Folkeoplysning, en høiere Vexelvirkning, der upaatvivlelig vil føre med sig, at hvad der allerede i mit Fædreland har været Gjenstand for meget omfattende og alvorlige Overvejelser, ogsaa snart i Norge og Sverige vil tildrage sig Opmærksomheden, dette nemlig, om ikke den nærværende Tids aandelige Vilkaar skulde fordre, at der lige overfor Universitetet, den lærde Høiskole, rejser sig en anden Høiskole paa folkeligt Grundlag, efter en stor Maalestok. Det er ikke nok med de smaa Bondehøiskoler, her behøves en Læreanstalt, hvilende paa et saa bredt Grundlag, at den kan omfatte de forskjellige Dannelsens og Vi- 
denskabens Elementer, vel at mærke saaledes, at Folkeoplysningens Grundtanke gjennemtrænger ethvert enkelt Element og behersker det hele."

Det var med sådanne tanker i baghovedet, at Nielsen var gået til kommissionsarbejdet, men uden mulighed for at få fornøden opbakning.

I senere skrifter uddybede Nielsen sine tanker, bl.a. i en afhandling i tidsskriftet "For Idé og Virkelighed " (1872), benævnt "Universitetsdannelse kontra Folkedannelse", indeholdende et forslag, der først 20 år senere skulle blive virkeliggjort ved nordiske universiteter. Det gik ud på, at en kreds af universitetslærere i fag som Historie, Statsøkonomi, Naturlære, Aandslære osv. frivilligt skulle træde sammen og organisere et kursus for højskolelærere:

„Ved Ordningen af et saadant Kursus vil der, naar man kun er enig om Aanden, naturligvis ikke tages Hensyn enten til grundtvigianske eller anti-grundtvigianske Sympatier, men til saadanne store og ledende Synspunkter, som videnskabelig Forskning har sikret, og som enhver Folkelærer, der vil rette sin Stræben mod det af Grundtvig stillede Maal, nødvendig maa have for Øie. Af slige Foredrag vil Almenheden da kunne skjønne, hvad Videnskaben formaaer til Folkeoplysningens Fremme, hvor meget Lys den fra sit Stade er i Stand til at sprede over virkelige nærværende Livsforhold. «

Nielsens tanker, der kan være inspireret fra engelske universiteter, som netop i 1872 organiserede tilsvarende kursus, blev med stort held virkeliggjort i Uppsala i august 1893, og det følgende år i Finland. Ved Askov Højskoles 50 års jubilæum i 1894 kunne forstander Alfred Povlsen fra Ryslinge i sin egenskab af formand for foreningen af højskolelærere meddele, at man agtede at gennemføre de første såkaldte universitetskurser for højskolelærere ved Københavns Universitet den følgende sommer. En tilnærmelse mellem videnskab og folkeoplysning var ved at finde sted. Men inden da havde tanken om en virkeliggørelse af Sorødrømmen gennemgået adskillige faser.

Et djærvt, men mislykket forsøg på ved privat initiativ at skabe en slags Sorøskole blev gjort af dr. phil. Gotfred Rode, som i 1874 
oprettede Skovgaard Højskole (ved København). Den var bestemt for unge mennesker, der ville bygge videre på, hvad de andetsteds havde begyndt på en af landets andre folkehøjskoler eller på anden vis. Den havde 6 lærere, hvoraf 4 var faste og underviste i de traditionelle højskolefag: fortrinsvis bibelkundskab, naturkundskab og samfundslære. Metoden var foredrag, men også selvstændig elevvirksomhed. Hertil kom, at skolen etablerede et artiumskursus for 6 elever.

Om sine ambitioner med Skovgaard Højskole skrev Rode 1. juni $1874 \mathrm{i}$ "Højskolebladet ", at han ønskede "at aabne Udvej for et efter Tidens Vilkaar afpasset Forsøg paa at sammenknytte folkelig og videnskabelig Oplysning, hvad der ligger i Højskoletanken fra dens Oprindelse og hvorefter den maa stræbe som sit sidste Maal ..."

"Naar det ... er almindeligt antaget som Faren ved den hidtidige lærde Dannelse, at den fjernet og løsrevet fra Folkelivet i dets Fortid og Nutid let kan ende $\mathrm{i}$ aandelig Indbildskhed og Magtesløshed, da tør man dog nok mene, at unge Mennesker, som samtidig med at indledes paa videnskabelig Vej, aldrig slipper den folkelige Oplysnings Grund, idet de daglig deltager i en historisk Undervisning, hvis Hovedøjemed er at oplyse og belyse hjemlige Tilstande i deres Sammenhæng med den verdenshistoriske Udvikling, og som lever i daglig Samvær med Lærere og Jævnaldrende, for hvem Folkeoplysningen er en Livssag, at de vil kunne undgaa hin Fare, der hidtil har gjort den videnskabelige Aandsdannelse til en Forargelse for Folkets sunde Sans og ladet den i Mangel paa Erkjendelse af dennes sande Værdi bidrage til at sondre i Stedet for at samle."

Rodes troskyldige argumenter for sit skoleprogram blev kraftigt imødegået af en af folkehøjskolens magtfulde væbnere, folketingsmand Harald Holm, som advarede mod at sammenblande højskolens og latinskolens virksomhed. Han måtte dog indrømme, at det lå "i Højskoletanken fra dens Oprindelse, at vi ogsaa med Tiden skal have en teoretisk videnskabelig Højskole, men den skal være af en helt anden Art end vort nuværende Universitet, og den skal staa $i$ et ganske andet Forhold til det folkelige Liv end dette."

Rodes tragiske død i 1878 reducerede Skovgaard-forsøget til en betydningssvag episode. Det var tydeligt nok ikke ukært for Holm, at virkeliggørelsen af Grundtvigs Sorøtanke lå et sted 
langt ude i fremtiden. I så henseende delte han håb med adskillige af samtidens ledende højskolefolk.

At grundtvigianerne stod delt, kom klart til udtryk på det møde i Tivoli i København, som en række ledende højskolefolk med dr. Jens Nørregård (Testrup) og Ludvig Schrøder (Askov) i spidsen kaldte sammen til i april 1878, og hvor man i to dage diskuterede ønskeligheden af at prøve på at få Sorøplanen taget op til virkeliggørelse. Bag aktionen stod - udover de to hovedmænd - en lille skare ældre og yngre grundtvigtilhængere (deriblandt den unge kirkehistoriker Fr. Nielsen) samt enegængeren fra Gylling, pastor Otto Møller. Han var vel at mærke ikke tilstede i Tivoli, men havde virket som inspirator til mødet ved udsendelsen af det smukke lille skrift: "Den danske Højskole, betragtet som en dansk Velfærdssag."

Både for ham og Nørregård (der $\mathrm{i}$ en blændende tale manede til kamp for at få taget Sorøplanen op til politisk afgørelse) blev aktionen en skuffelse. Alt for mange af højskolernes folk var valne eller gik direkte imod planen - vistnok fordi de frygtede for virkningerne på deres egne skoler, men officielt fordi de principielt var imod en statshøjskole, selvom Grundtvig havde argumenteret for, at det skulle være en sådan, bl.a. ved ofte at benævne den "den kongelige Højskole". Den hele aktion endte med, at Schrøder fik Rigsdagen til at bevilge $5.000 \mathrm{kr}$. årlig til etableringen af det udvidede nordiske kursus i Askov. Ikke uden bitterhed skrev Otto Møller til sin ven Thomas Rørdam:

"Jeg kan ikke se rettere, end at denne Sag er blevet forraadt af dem, der skulde have været dens Forsvarere. Ingen tør nægte, at Grundtvig holdt Tanken fast lige til sin Dødsdag; men det er meget faa af Grundtvigs Venner, som nu vil vide af den at sige. Politiken har ogsaa gjort Udslaget, den afviser en Statsskole, og Schrøder, som er en klog Mand, der mærker, hvorhen Vinden blæser, sætter sine Sejl op og opfanger al den Vind for sig, som han kan. Og det, som han stiller an, kan dog ikke blive til noget, som det er værd at tale om; men imidlertid ruller Stenen ned igen, og der er vel lange Udsigter til, at der kan røres ved den." 
Det varede nu ikke så længe, førend sagen fik ny aktualitet. Tivolimødet fik uventede politiske følger. Estrups frisindede, for ikke at sige åndeligt radikale, kultusminister, I.C. Fischer, forelagde i rigsdagssamlingen 1878-79 ret overraskende et lovforslag om oprettelsen af en statshøjskole, vel at mærke beliggende $i$ København eller denne by's nærhed.

I sin forelæggelsestale karakteriserede ministeren et par gange den påtænkte højskole som et "folkeligt Universitet", ligesom Berg i sit indlæg i debatten talte om et "Folkeuniversitet", vistnok det ældste belæg, man har på tryk for dette ord. Fischer understregede desuden, at der ikke ville være det mindste "til Hinder for, at Højskolen i Kjøbenhavn kan forliges med Universitetet; jeg vil gaa et Skridt videre og paastaa" (sagde han), "at jeg ikke ser rettere, end at Universitetet i høj Grad vil kunne gavne en Højskole i Kjøbenhavn, og omvendt, at Højskolen vil kunne gavne Universitetet. "

På sine gamle dage havde Grundtvig som bekendt sagt så mange hårde ord om Universitetet og den sorte skole, at hans venner næsten måtte tro, at Universitetet var selve djævelens højborg. Det var derfor forståeligt, men ikke ganske rimeligt, at mange af "den Gamle"s arvtagere lod sig skræmme af Fischers tale om et forsonligt forhold mellem videnskabens hovedsæde og en statshøjskole for nordisk folkeoplysning - og det uagtet at opbygning og formål lå tæt op ad, hvad Grundtvig havde gjort sig til talsmand for i sine højskoleskrifter, at fagene var de af Grundtvig foreslåede, at adgangen skulle være fri "for saadanne unge Mennesker, der ikke har studeret", således at de kunne føres et skridt videre, inden de gik over i deres livsstilling - og at ingen examiner skulle afholdes.

Fischers plan blev ikke gennemført, men endte, som antydet med bevillingen af de $5.000 \mathrm{kr}$. til Askov udvidede folkehøjskole. Men snart dukkede nye forslag frem. Under en debat i Folketinget det følgende år (17/11 1879) fremkom der et bemærkelsesværdigt forslag fra et medlem, skolebestyrer F.C.B. Dahl, gående ud på oprettelsen af et sjette fakultet ved Københavns Universitet. Dahl ville kalde det "det populærvidenskabelige Fakultet " og, sagde han, "dette skulde repræsentere denne Tanke om en Højskole i Sorø."

Han understregede sin tro på betydningen af, 
"at der gives en populær Videnskabelighed, og det er den, jeg her har troet og vist med rette har troet, at man ville have repræsenteret ved Højskolen i Sorø. Dette sjette Fakultet ved Kjøbenhavns Universitet vilde jeg da tænke mig sammensat af de mest fremragende af vore Folkehøjskoleforstandere samt dem af Universitetslærerne, som ville støtte denne sag".

I den følgende debat hævdede Harald Holm, at Dahl havde taget fejl af den målsætning, der var fremherskende hos Sorøplanens forkæmpere. De ønskede ikke en populær udgave af et universitet, derimod en "Dannelsesanstalt ..., hvor det især kom an paa at danne Personligheden".

Heri havde Holm i nogen måde ret. Tilbøjeligheden til at dreje tanken om den "kongelige Højskole" over i retning af en form for dansk university extension, som allerede sporedes i Fischers forslag, var hos Dahl blevet yderligere accentueret.

Det blev iøvrigt ikke sidste gang, at Sorøtanken og planerne om et dansk Folkeuniversitet tangerede hinanden. Den folkelige universitetsundervisnings historie i Danmark lader sig ikke skildre, uden at man kommer ind på Sorøtankens historie, ligesom det ikke synes muligt at følge Sorøtankens udvikling uden at rette blikket mod det arbejde, som gik forud for tilblivelsen af det danske Folkeuniversitet. Sagen bliver ikke mindre kompliceret af den kendsgerning, at såvel Sorøtanken som planerne om et dansk Folkeuniversitet ikke er uden forbindelse med det mangeårige forarbejde, der gik forud for tilblivelsen af Aarhus Universitet. Det lyder kompliceret og er det for så vidt også. Men de indfiltrede tråde kan udredes.

Der kom, som antydet, ingen realiteter ud af Fischers eller Dahl's forslag fra 1878-79. Men i det følgende år dukker Sorøtanken op på en ny måde. En af de folketingsmænd, der havde støttet Fischers plan om en statshøjskole i København, dr. phil. Geert Winther søgte i begyndelsen af 1880erne samarbejde med Fischer om et lovforslag om oprettelsen af en statshøjskole i Århus. Dens opgave skulle være: "i saa vide Kredse som muligt at udbrede og vække Interesse for nyttige Kundskaber - samt at fremkalde Kjærlighed til, hvad der bidrager til at forædle, hæve 
og pryde Livet«. Der skulle være gratis adgang for alle, meddelelsens form skulle være foredrag, og ingen examiner skulle afholdes. Fagene skulle så vidt muligt være de samme, som var knyttet til Sorøplanen: dansk sprog og litteratur, historie (herunder kunsthistorie og kirkehistorie), geografi, naturhistorie, naturvidenskab, filosofi, dansk statsforfatning og kommunallovgivning. Slægtskabet med Fischers plan for et københavnsk "Sorø" er tydeligt nok. Den var et barn af denne, der atter var et barn af Grundtvigs Sorøplan. Men stamfaderen blev ikke nævnt. I.C. Fischer var - skønt Højres mand - en ateistisk naturvidenskabsmand med udtalte radikale meninger om tilværelsen, og Winther tilhørte Bjørnbakkerne, der lå i evig strid med "højgrundtvigianerne", først og fremmest Jens Nørregård på Testrup. Men tanken om en statshøjskole, hvis undervisning kunne berige deres kundskaber, "der agter at gaa over til Livets praktiske Virksomhed uden at have haft Lejlighed til at erhverve videnskabelig Fordannelse, vække deres Agtelse og Kjærlighed til det Store, det Gode og Skjønne" - som det siges i forslaget ligger i klar forlængelse af Grundtvigs Sorøvisioner.

Det mest radikale i forslaget var savnet af kristendomskundskab som centralt fag (reduceret til kirkehistorie som et led i faget historie), men ikke mindre forslaget om at flytte placeringen fra Sorø til Jyllands hastigt voksende hovedby, motiveret med hovedlandets totale mangel på betydende kulturinstitutioner.

Lovforslagets text blev sat på Rigsdagens trykkeri, men ikke trykt. Just som trykningen skulle ske, udskrev Estrup valg til Folketinget. Ved valget faldt Winther (der havde været medlem af Tinget siden dets åbning i 1849), og kort efter valget i 1884 døde Fischer. Først så sent som i 1893 lod Winther forslaget trykke i sit blad "Nørrejydske Tidende" - på et tidspunkt, hvor han øjnede en chance for at få sin plan om oprettelsen af en videnskabelig højskole i Århus - udvidet med, hvad han betegnede som "et Net af Arterier", små lokale kulturcentre fordelt over hele Nørrejylland - virkeliggjort.

Grunden til hans optimisme var opdukkende tanker om etableringen af en dansk university extension, en dansk, folkelig universitetsundervisning efter engelsk mønster. Helt til sin død (i 1905, 92 år gammel) søgte han med stor udholdenhed at få sine 
tanker omsat til virkelighed. Skildringen af den sidste fase af hans arbejde for sagen må imidlertid vente en lille stund endnu.

For at få alting med, må vi gå tilbage i tiden og nævne, at Fischers efterfølger som kultusminister, Jacob Scavenius, i forbindelse med et forslag til en ny skolelov - i 1885 - i et par af forslagets paragraffer fremsatte en udarbejdet plan til en statshøjskole $\mathrm{i}$ lighed med Fischers og Winthers plan. Den lå dog den grundtvigske Sorøplan en smule nærmere, bl.a. ved at have kristendomskundskab med i læseplanen, og var forøvrigt den første af de alternative Sorøplaner, der udtrykkelig forudsatte, at højskolen skulle drives for Sorø Akademis midler. Den lagde sig ikke fast på placeringen, men antydede, at København eller Københavns nærhed ville blive det gunstigste sted. Til planen knytter sig den pikante kendsgerning, at Scavenius - $i$ al gedulgthed havde modtaget råd og vejledning til dens udformning af en af tidens ansete teologer, den førnævnte grundtvigsk-orienterede, lærde kirkehistoriker, professor Fredrik Nielsen. Han var, som det vil erindres, en af bagmændene ved Tivolimødet i 1878, altså en klar tilhænger af Sorøtankens virkeliggørelse. Man møder Fr. Nielsen igen som forkæmper for en videnskabelig højskole med hjemsted i Århus - ved overgangen fra det nittende til det tyvende århundrede.

Men det var ikke blot Grundtvigs disciple, der i det nittende århundredes sidste årtier tog hans tanke om en stor folkelig højskole op til positiv drøftelse. Der var endda folk, som ved fødsel og herkomst stod Grundtvig fjernere end både Fischer og Winther, som sluttede op om hans folkepædagogiske visioner. En af dem var filologen og geologen Victorinus Pingel. Han havde ganske vist 1881 været inde på den drilske tanke at slå grundtvigianerne og andre kristne i hovedet med Grundtvigs store plan, for så vidt som han i et brev til Georg Brandes havde luftet tanken om oprettelsen af et "frit Universitet « i København til værn for "Fritænkeriet " og med front mod grundtvigianerne! Ikke desto mindre var han en stor beundrer af Grundtvigs pædagogiske idéer og havde allerede i 1878 karakteriseret Grundtvig som "denne 
store skabende Aand, det eneste pædagogiske Geni, som Danmark endnu har frembragt."

Ti år senere træffer vi ham på Folketingets talerstol (valgt $\mathrm{i}$ Århus), hvor han gør sig til talsmand for en videnskabelig højskole i Århus, et moderne universitet, der kunne blive en modvægt mod det gamle, forbenede universitet på Frue Plads, for så vidt som det skulle være forpligtet til at arbejde i folkeoplysningens tjeneste!

Året før havde han fremsat et forslag om, at embedsmændene ved landsarkiverne skulle forpligtes til at holde folkelige historiske foredrag rundt om i provinserne, og ført rent .grundtvigsk tale, idet han ønskede at bringe arkivarerne $» i$ levende Vekselvirkning med det levende Folk og tale det levende Ord om de Ting, som ligger dem paa Hjertet ".

En anden radikaler, som lod sig inspirere af Grundtvig, var forfatteren til "Det haver saa nyeligen regnet", skoleinspektør Johan Ottosen. Han tog anledning af Winthers offentliggørelse af planen om en videnskabelig højskole i Århus til at skrive en stor artikel (i "Aarhuus Amtstidende") med titlen: "En udvidet Højskole i Aarhus". Han ville - ligesom Winther - ikke have et egentligt universitet i Århus. "Universiteter, som vi kender dem i Tyskland og Skandinavien, slæber endnu stadig et Stykke af det 16. og 17. Aarhundrede med sig ". Han ønskede derimod "den sunde og i sin Kjærne uimodsigelig rigtige Tanke, Grundtvig havde om en stor folkelig Højskole, hvor Unge af alle Stænder paa Modersmaalet kunde vinde videnskabelig og borgerlig Dannelse " virkeliggjort i Århus. Hvad undervisningen angik, ønskede han lærernes foredrag suppleret med samtaler og skriftlige øvelser, ligesom han ønskede undervisning i nordisk historie og ikke bare Danmarkshistorie. Han ønskede ligeledes matematik gjort til en hoveddisciplin og savnede i Fischer-Winther-planen nationaløkonomi eller samfundskundskab.

Ottosens plan vakte bekymring i Askov, hvor man gerne så den udvidede nordiske folkehøjskole accepteret og udbygget som den endegyldige udformning af Sorøtanken. Askovs talsmand, dr. Marius Kristensen havde dog ikke andre argumenter, end at der næppe ville være kvalificerede lærere til både Askov og Århus! 
Johan Ottosens artikel havde form af et supplerende svar på Winthers i 1893 (og 1894!) offentliggjorte plan fra 1884 (FischerWinther-planen). På Winthers initiativ samledes i 1894 en kreds af århusborgere i konsul Rudolph Wulffs hjem for at drøfte muligheden af gennem et borgerinitiativ at få virkeliggjort Winthers plan. Man forestillede sig muligheden af at lave noget lignende, som borgere i Göteborg havde udrettet, da de i 1891 kunne indvi Göteborgs Högskola (idag det Kgl. Universitet i Göteborg). Her var tale om en højere læreanstalt (et "privat " humanistisk fakultet), oprettet ved store donationer fra rigmænd i Sveriges næststørste by, og støttet af bystyret i Göteborg. Men det, som optog Winther og hans århusianske medkæmpere mest, var, at Göteborgs Högskola skulle være et frit akademi, hvor der både blev forsket og uddannet akademikere og givet en folkelig universitetsundervisning.

Nogle af de førende forkæmpere for en "Högskola" i Göteborg var i begyndelsen af 1860erne blevet grebet af Grundtvigs tanker om en skole for livet og havde gerne set den nye læreanstalt i Göteborg udformet som et helt frit akademi, et svensk Sorø. De fik undsætning af Bjørnson, som i foråret 1873 holdt en række stærkt besøgte forelæsninger i den svenske vestkystby om Grundtvig. Han befordrede ved denne lejlighed Grundtvigs tanker om skolen i Soer til Sverige!

Den århusianske komités planer om at oprette en pendant til den unge Göteborgs Högskola i Århus havarerede som følge af konsul Wulffs død i 1895.

Men gamle Geert Winther gav ikke op. Da tanken om et dansk folkeuniversitet blev en realitet (1898) dukkede han påny frem. Han bragte i 1900 et møde i stand mellem nogle af de i folkeuniversitetssagen interesserede professorer og fik nedsat et udvalg på fem medlemmer - et for hvert fakultet - til at drøfte muligheden af et samarbejde med den folkelige universitetsundervisning med henblik på etableringen af den videnskabelige højskole $i$ Århus. En af de fem professorer, repræsentanten for det teologiske fakultet, var Fredrik Nielsen! - Han mødte op med en revision af den plan, han i 1885 havde udarbejdet til brug for statshøjskoleparagrafferne i Scavenius' skolelovsforslag. 
Det ser ud til, at planen mødte heftig modstand på et møde, som afholdtes i København i 1902, og hvor en række universitetsprofessorer var til stede. Et flertal af disse stillede sig afvisende over for akademi-tanken (som Fr. Nielsen kaldte sin plan til en videnskabelig højskole). De krævede et "klassisk « dansk universitet.

Fr. Nielsen lod sig dog ikke slå ud af denne modstand. Han blev i 1906 biskop i Århus, og det inspirerede ham til et nyt forsøg på at skabe et slags Sorø i den jydske hovedstad. Ved indvielsen af Aarhus Katedralskoles nye bygning på Kystvejen i juni 1906 holdt han en tale, hvori han bl.a. nævnede, at han sekssyv år tidligere sammen med nogle professorkolleger havde drøftet:

"Planen til et Akademi uden for Universitetet, som ved Siden af dette kunde meddele en saadan almendannende Undervisning og $\mathrm{i}$ visse Maader kunde være en Udførelse af Grundtvigs Tanke om Højskolen i Soer. " - "et Akademi, der skal blive Hjemstedet for "de frie Kunster" i Nutidens Forstand og for et Fællesliv mellem Lærere og Lærlinge, et Mødested ikke alene for vordende Embedsmænd, men for alle, som ønsker en videnskabelig Almendannelse. Et saadant Akademi vil ligesom Middelalderens Universiteter i dens Begyndelse, kunne blive en i Sandhed demokratisk Indretning, hvor den fremmeligste Del af Landets Ungdom mødes, og tit maaske ogsaa ældre. «

Men Fr. Nielsen skulle ikke se sin drøm om et Århus-Akademi opfyldt. Sammen med en række fremtrædende århusborgere forelagde han sine planer for en forsamling af rigsdagsmænd og professorer ved et møde i Wivels selskabslokaler i København den 26. februar 1907. Forsamlingen enedes om at rette en henvendelse til kultusministeren om at regeringen tog spørgsmålet om oprettelsen af "en dansk videnskabelig Højskole (Universìtet) " $\mathrm{i}$ Århus op til drøftelse. Man mærker sig udtrykket: "en dansk videnskabelig Højskole" (modsat en latinsk (!)) samt at ordet Universitet er vedføjet i parentes.

Da Københavns Universitet i september 1907 svarede på en høring fra kultusministeriet, var betegnelsen "en dansk videnskabelig Højskole " forsvundet! Professorerne på Frue Plads udtalte sig (forøvrigt ret positivt) om et Universitet.

Selvom vi kun har spredte referater af Wivelmødets forløb, er det tydeligt at et flertal af deltagerne har udtalt betænkeligheder 
ved tanken om en dansk videnskabelig Højskole, men sympati for et jydsk universitet. I virkeligheden fik Geert Winthers "Sorø-plan" dødsstødet på Wivelmødet. At Fr. Nielsen kort efter mødet blev syg og døde, er næsten symbolsk. Men endnu så sent som i 1920 talte Fr. Nielsens gamle kollega og medkæmper professor Harald Høffding ved et møde på Århus rådhus om "en videnskabelig Højskole« - med arbejdende videnskabsmænd som lærere, "der gennem mere tilgængelige, mere populære Forelæsninger (skulle give) en almendannende Undervisning, som (kunne) komme større Kredse tilgode ..." - Det var vistnok sidste gang, at Geert Winthers og Fischers - med Sorøplanen beslægtede - tanker førtes frem med en forskers autoritet i en seriøs debat om et lærdomssæde i Århus.

Men hvor stod folkehøjskolens folk i denne sag?

Ja, Ludvig Schrøder og Askovfolkene var ikke interesserede i en konkurrent til den udvidede Folkehøjskole i Askov. Og på Testrup havde Jens Nørregård svært ved at forsone sig med andre planer end den grundtvigske kongelige højskole i Sorø.

En særstilling indtog dr. phil. Laust Moltesen, der tidligt blev en varm forkæmper for Folkeuniversitetsarbejdet, og som vel at mærke tillige delte Geert Winthers ønske om en videnskabelig højskole i Ârhus. Han gav udtryk herfor i en temperamentsfuld tale på et møde, arrangeret af Foreningen for Højskoler og Landbrugsskoler, i Odense 1. februar 1912 (i anledning af en forestående revision af Højskoleloven). Han sagde bl.a.:

"Der er Trang til et Folkeuniversitet, ikke i Sorø, men i Jylland, f.eks. i Aarhus. Dertil vil det sikkert komme en Gang. Men det vil blive dannet ikke efter det middelalderlige Skema, som vort nuværende Universitet, men befrugtet af Højskolen, Grundtvig og Kold. «

Han beklagede sig over, at staten havde lagt sig på Sorø Akademi's midler, og ønskede, at Højskolens folk hver aften ville bede til, at en rigmand skænkede de nødvendige midler til et jydsk Sorø!

Den indledende taler på Odensemødet var forstanderen for Aagaard Højskole, pastor Valdemar Brücker, som siden 1909 hav- 
de startet en agitation for genoptagelse af kampen for virkeliggørelse af Sorøtanken. Nu søgte han - i en visionrig og udfordrende tale - at genopvække interessen for en ajourført virkeliggørelse af Grundtvigs plan om "en anstalt, hvor folkelighed og videnskabelighed skal mødes, for at folkeligheden kan blive oplyst om sig selv, og videnskaben hjælpes til at træde $i$ det virkelige livs tjeneste. Den (skolen) skal udspringe af lærdommen og stå i levende forbindelse dermed ... Den skal næres af den danske ånd."

Hvad Brücker sigtede imod, var en folkelig, dansk almendannelse, som kunne tilkæmpe sig jævnbyrdighed med den akademiske. Sorøskolen skulle ikke være "Højskolernes Universitet ", men heller ikke "en Skole for Begyndere". Der skulle ikke være examiner og ikke bestemte afgrænsede kurser. Den enkelte elev skulle selv kunne bestemme, hvor længe han ville blive på skolen, ganske som på et universitet. Men havde man gennemgået en af de grupper, hvor undervisning blev meddelt, skulle det uden videre give adgang til universitetet. Der skulle på Sorøskolen være adgang for alle, også fritæenkere! både blandt lærere og elever, og selvsagt også arbejdere. Det skulle ikke være en kristelig skole som den udvidede skole i Askov (hvis virke han ikke havde høje tanker om), men først og fremmest en skole, der var præget af dansk ånd.

Brücker måtte lide den tort, at hans forslag om at genoptage kampen for at få oprettet skolen i Soer blev stemt ned - til fordel for en udvidelsesplan for Askov. Stemmerne stod 21 over for 16.

Med en række trofaste kampfæller (som Tormod Jorgensen, Jacob Lange, A. Vedel samt adjunkt Ussing i Sorø og redaktør Axel Garde) søgte Brücker at hele skårene og udforme en gennemførlig plan for, hvad han nu kaldte "den almendannende Rigshøjskole", en ny plan for oprettelsen af et nyt Sorø Akademi, som i hovedtrækkene havde lighed med Jens Nørregårds plan fra Tivolimødet i 1878 men også med Geert Winther-Fischerplanen fra 1884 og Scavenius-Fr. Nielsen-planen fra 1885. Men ejendommeligt nok henviste Brücker og hans folk kun til den havarerede og hos alle parter upopulære Betænkning af 1867 !

Den nye debat om Sorø nåede ind i Rigsdagen, men førte iḱke til noget politisk resultat - til Brückers sorg og beklagelse. Hvor stor betydning han tillagde Sorø-tanken, fremgår af de ord, 
hvormed han slutter sine Erindringer ("Mit Livs Vej“ 1922): "Om der da i dette århundrede blev med alvor og kraft taget fat på arbejdet, så vi kunde vinde fuld frihed i folkekirken og fă rejst Skolen i Soer! Da tror jeg, at der endnu kunde blive åndelig grødetid i Danmark. «

Var dette så slutningen på Sorøtankens lange eftervirkninger?

Ikke ganske. Den spøgte en smule i højskolekredse omkring 1930, muligvis som et modtræk mod den begyndende "Universitetsundervisning i Århus «, der startede i september 1928, men også foranlediget af 100 året for fremkomsten af Grundtvigs første skrifter om en højskole i Sorø.

Ved samme tid betegnede Holger Begtrup i en artikel i „Højskolebladet" Grundtvigs højskoleskrifter som "gamle Papirer, som fremstillede en Plan, der heldigvis ikke kom til Udførelse(!) «, medens professor I.P. Bang benyttede lejligheden til i samme blad at minde om Otto Møllers bog fra 1878, hvori Møller nægtede at "istemme den sorte Tale om, at det kun er Mørke og Forfinelse, der fra Universitetet naar til Folket, " og som i Sorøskolen så "et Mellemled, som det er en Lykke, hvis det ikke er for silde at faa bragt ind ... en folkelig Højskole, der kun kan faa sit Lys registreret fra den lærde og oversætte den i den Form, der kan komme det hele Folk til gode."

Bang sluttede sin artikel med at sige, at "Grundtvigs store Tanke skulde aldrig blive til Virkelighed", mens "Højskolebladet «S redaktør, Helge Skovmand, mente, at Sorøtankens fremtid "stod skrevet i Stjernerne". Han trøstede sig og sine læsere med, at der vist var noget om, "at det er med Sorø-Tanken ligesom med den sovende Holger Danske ved Stenbordet i Kronborgs Kælder: naar der er Uro i Luften, saa vaagner han."

Han fik for så vidt ret, som det initiativ, der efter besættelsen førte til oprettelsen af Krogerup Højskole - med Hal Koch som forstander - tenderede i retning af en med Sorøtanken beslægtet institution. Men virkeliggørelse af Grundtvigs store visioner blev det ikke til, hverken i Nordsjælland - eller i Kungälv. 